\title{
ANALYSIS OF THE INFLUENCE OF GAMIFICATION ELEMENTS IN SALES MANAGERS INTERNSHIP
}

\author{
ANALIZA WPEYWU WYKORZYSTANIA \\ MECHANIZMÓW GRYWALIZACYJNYCH \\ W PRAKTYKACH MENEDŻERÓW SPRZEDAŻY
}

\begin{abstract}
The purpose of this publication is to present example of using gaming mechanism in practice program created for sales managers in insurance company. Final result analysis and questionnaires at the end of each group showed that there are important differences in final effect between module which had only one gaming mechanism and module with many gaming mechanisms at the same time. The more gamified module resulted the better final rating. During evaluation by NPS (Net Promoter Score) method, employees pointed out gamified modules are much more attractive despite off bigger difficulties and time limits. They were choosing gamified modules as the best, much more often than the others.

\section{STRESZCZENIE}

W artykule przedstawiono koncepcję wykorzystania wybranych mechanizmów grywalizacyjnych w praktykach zaprojektowanych dla menedżerów sprzedaży. Analiza wyników końcowych menedżerów oraz ankiet przeprowadzonych po zakończeniu praktyk wykazały istnienie istotnych różnic pomiędzy rozwiązaniami, w których zastosowano jednocześnie kilka mechanizmów grywalizacyjnych, a tymi, w których pojawił się tylko jeden lub żaden. Moduły, w których wykorzystano więcej niż jeden element grywalizacyjny, uzyskały lepsze wyniki końcowe. Podczas oceny metodologią NPS (Net Promoter Score) moduly zostały ocenione jako atrakcyjniejsze mimo trudności i ograniczeń czasowych oraz częściej wskazywano je jako najlepsze.
\end{abstract}


KEYWORDS: gamification, employee engagement, engagement, commitment, motivation

SŁowA KLUCzowE: grywalizacja, gamifikacja, zaangażowanie pracowników, zaangażowanie, motywacja

\section{WPROWADZENIE}

Zmieniające się otoczenie zmusza kadrę kierowniczą do działań dostosowanych do zachodzących zmian. Podkreśla się rolę wiedzy jako czynnika sukcesu organizacji, która stała się źródłem przewagi konkurencyjnej, podobnie jak doświadczenie oraz lojalność. W organizacjach opartych na wiedzy wyjątkowego znaczenia nabiera analiza zaangażowania pracowników dysponujących dużą wiedzą i doświadczeniem. To oni kreują przyszłość firmy zdobywając nowe rynki, produkty i usługi. Efektywne zarządzanie wiedzą uzależnione jest od warunków, które panują w organizacji. Dotyczy to przede wszystkim ogólnego dostępu do informacji, ciągłego procesu rozwoju zawodowego każdego z pracowników, a także poczucia przynależności do firmy.

Po raz pierwszy słowo "gamification” (w polskim tłumaczeniu grywalizacja lub gamifikacja) pojawiło się w 2002 roku, a jego autorem był Nick Pelling. A jednak sama grywalizacja zyskała na popularności dopiero po 2010 roku (Marczewski, 2015, s. 10). W Polsce za najpopularniejszą definicję grywalizacji uznaje się tę autorstwa Pawła Tkaczyka, który za grywalizację uznaje przenoszenie mechanizmów growych do sytuacji, które grami nie są, aby wpływać na ludzkie zachowania (Tkaczyk, 2012, s. 10). Jednakże znacznie bardziej trafną jest ta autorstwa Andrzeja Marczewskiego, według którego grywalizacja jest to stosowanie rozwiązań growych celem stymulowania większej ilości angażujących - podobnie jak w grach - działań (Marczewski, 2015, s. 10).

Obecnie po wpisaniu hasła „gamification” w wyszukiwarce Google możemy otrzymać ponad osiem milionów wyników, z czego około trzydzieści pięć tysięcy z nich to publikacje naukowe w Google Scholar. Z praktycznym wykorzystaniem grywalizacji najczęściej można się spotkać w marketingu, przy projektowaniu rozwiązań mających na celu angażowanie klientów i budowanie ich lojalności oraz w edukacji. Obecnie znajduje swoje zastosowanie w wielu innych kierunkach zarządzania, a jednak w naukach o zarządzaniu nadal 
nie zyskała na popularności, dlatego dociekliwi naukowcy mogą znaleźć jej przykłady tylko w nielicznych polskich publikacjach, gdzie słowo grywalizacja uzyskuje zaledwie 383 wyniki, a gamifikacja 186 wyników w Google Scholar.

Skoro grywalizacja to wdrażanie mechanizmów z gier do sytuacji, które grami nie są, aby wpływać na zachowania i zaangażowanie uczestników, to takie zastosowanie wydaje się być idealnym rozwiązaniem w budowaniu lojalności klienta. A co jeśli za naszych klientów wewnętrznych potraktujemy zatrudnionych w danej organizacji pracowników? Czy na nich mechanizmy grywalizacyjne zadziałają tak samo? Aby odpowiedzieć na te pytania, w pierwszej kolejności warto omówić przykładowe mechanizmy stosowane w grywalizacji, które przedstawiono w tabeli 1, a które potrafią zaspokoić potrzeby określone w piramidzie Maslowa bez konieczności zachowania kolejności tych potrzeb od niższego do wyższego rzędu.

Tabela 1.

Przykładowe mechanizmy stosowane w grywalizacji

\begin{tabular}{|c|c|}
\hline Potrzeba ludzka wg piramidy Maslowa & Mechanizm grywalizacyjny \\
\hline Potrzeby fizjologiczne & Symulacje \\
\hline \multirow{2}{*}{ Potrzeba bezpieczeństwa } & Artefakty \\
\cline { 2 - 2 } & Jasne i proste zasady \\
\cline { 2 - 2 } & Szkolenie wprowadzające \\
\cline { 2 - 2 } & Storytelling \\
\hline \multirow{4}{*}{ Potrzeba przynależności } & Szybka informacja zwrotna \\
\cline { 2 - 2 } & Społeczność \\
\cline { 2 - 2 } & Współpraca \\
\hline Potrzeby uznania i samorealizacji & Rywalizacja \\
\cline { 2 - 2 } & Status \\
\cline { 2 - 2 } & Wyznaczone cele \\
\cline { 2 - 2 } & Odznaki \\
\cline { 2 - 2 } & Punkty \\
\cline { 2 - 2 } & Nagrody \\
\cline { 2 - 2 } & Poziomy \\
\hline
\end{tabular}

Źródło: opracowanie własne (na podstawie: Paharia, 2014, s. 93-110 oraz Czerska, 2002, s. 310). 


\section{Praktyki Z Elementami gryWALIZACJI W RAMACH PROGRAMU ROZWOJOWEGO}

Przykład zastosowania grywalizacji przedstawiony w poniższym artykule wykorzystano jako eksperyment w ramach programu rozwojowego dla menedżerów sprzedaży, którego celem było rozwijanie kompetencji menedżerskich w zakresie wiedzy merytorycznej o procesach realizowanych w firmie oraz rozwój poczucia utożsamienia z firmą poprzez kształtowanie postawy ambasadora marki firmy ubezpieczeniowej. W ramach tych celów, każdy ze 100 zatrudnionych menedżerów sprzedaży obowiązkowo wziął udział w praktykach w centrali firmy. W trakcie czterech dni, dla menedżerów przygotowano grę w formie ośmiu modułów szkoleniowych, z których każdy w różny sposób ukazywał codzienną pracę kluczowych obszarów, z którymi menedżerowie mają kontakt. W poprzednich latach praktyki było prowadzone tradycyjnie, gdzie każdy menedżer mógł przyjechać do siedziby firmy, aby przez dwa tygodnie pracować w jednym wybranym przez siebie obszarze. Aby sprawdzić skuteczność grywalizacji, zmieniono dotychczasowe rozwiązanie. Badania zrealizowano od początku lipca do końca września 2017 roku w jednej z czołowych firm ubezpieczeniowych. Pracownicy reprezentowali różnorodną grupę wiekową: pomiędzy 24. a 58. rokiem życia. Głównym kryterium doboru grup była lokalizacja. W każdej grupie każdy menedżer sprzedaży musiał być z innej spośród 24 lokalizacji w Polsce. Dwoma kolejnymi był staż pracy oraz wiek. Przyczyną, dla której wybrano akurat taki dobór grup, było ich możliwie maksymalne zróżnicowanie, aby wzmocnić integrację uczestników, wymianę doświadczeń oraz wiedzy.

Pierwszy mechanizm, który wykorzystano przy projektowaniu praktyk, to fabuła, czyli tzw. storytelling. Na początku każdy z uczestników otrzymywał mapę, która miała pomóc w podróży przez firmę. Pierwsza strona mapy zawierała harmonogram praktyk wraz z lokalizacjami wszystkich modułów, do których menedżerowie musieli dotrzeć samodzielnie. Tam zamieszczono również ukryte skarby do zdobycia, które nie wpływały na przebieg gry, ale mogły uatrakcyjnić sposób spędzania wolnego czasu w przerwach między modułami. Na drugiej stronie znajdowała się fabuła gry, wskazówki do rozpoczęcia gry oraz pięć misji do zrealizowania, a także bonusowa karta 
kontaktów do zebrania, która umożliwiała zdobycie dodatkowych punktów w grze. Na samym końcu pozostawiono również kontakt do mistrza gry, który koordynował przebieg gry przez wszystkie cztery dni. Istotnym czynnikiem w grze była tajemnica. Uczestnicy wiedzieli, gdzie i o której mieli się pojawić. Nie wiedzieli, czego będzie dotyczył moduł ani co się na nim wydarzy. Dodatkowo każdy z uczestników otrzymywał kartę wejściową umożliwiającą swobodne przemieszczanie się po wszystkich budynkach bez potrzeby standardowego nadzoru.

Każdy z ośmiu modułów był projektowany indywidualnie i zawierał inne mechanizmy lub nie było ich wcale. Dobór mechanizmów był zależny od otwartości prowadzących poszczególne moduły na mechanizmy grywalizacyjne. Mechanizmy dobierano dowolnie, niezależnie od tematyki modułu. W tabeli 2 przedstawiono, jakie mechanizmy wykorzystano w poszczególnych modułach.

Tabela 2.

\section{Zestawienie modułów i wykorzystanych w nich mechanizmów grywalizacyjnych}

\begin{tabular}{|c|c|}
\hline $\begin{array}{l}\text { Numer } \\
\text { modułu }\end{array}$ & Wykorzystane mechanizmy \\
\hline 1 & Wyznaczony cel, szybka informacja zwrotna. \\
\hline 2 & Brak. \\
\hline 3 & Wyznaczony cel, szybka informacja zwrotna, współpraca. \\
\hline 4 & Brak. \\
\hline 5 & $\begin{array}{l}\text { Jasne i proste zasady, szybka informacja zwrotna, współpraca, rywalizacja, } \\
\text { wyznaczone cele, punkty, nagrody. }\end{array}$ \\
\hline 6 & $\begin{array}{l}\text { Artefakty, jasne i proste zasady, storytelling, szybka informacja zwrotna, } \\
\text { społeczność, współpraca, rywalizacja, status, wyznaczone cele, punkty, nagrody, } \\
\text { poziomy. }\end{array}$ \\
\hline 7 & Brak. \\
\hline 8 & Artefakty, jasne i proste zasady, storytelling, społeczność. \\
\hline
\end{tabular}

Źródło: opracowanie własne.

Na koniec ostatniego modułu menedżerowie sprzedaży dokonywali oceny poszczególnych modułów oraz podsumowywane były wyniki punktowe 
danej grupy. Na koniec wszystkich praktyk stworzono zestawienie wyników poszczególnych grup wraz z ich oceną. Ocena praktyk przez menedżera sprzedaży przeprowadzona została metodą NPS (Net Promoter Score).

NPS (Net Promoter Score) jest to proste narzędzie, dzięki któremu można zwiększać zyski firmy poprzez analizę opinii klientów (Reichheld, 2003, s. 8-10). Wystarczy zadać klientowi (a w tym przypadku - pracownikowi) tylko jedno pytanie: Na ile poleciłbyś/poleciłabyś firmę/produkt/usługę/rozwiązanie swojemu znajomemu? Badany zaznacza swoją odpowiedź według dziesięciostopniowej skali, gdzie 0 oznacza, że w ogóle nie poleciłby rozwiązania, a 10 - poleciłby z pewnością. Po zebraniu wyników wszystkich ankiet respondentów dzieli się na (Perenc, 2004, s. 290):

- promotorów (wskaźniki 9 oraz 10), którzy są pozytywnie nastawieni do organizacji i aktywnie polecą rozwiązanie innym oraz są lojalni, więc budują wizerunek pracodawcy;

- biernych (wskaźniki 7 oraz 8), czyli osoby, które akceptują firmę czy proponowane rozwiązanie, ale nie będą lojalni i przy pierwszej lepszej konkurencyjnej ofercie - skorzystają z niej;

- krytyków (wskaźniki od 0 do 6) - czyli niezadowolonych z firmy lub proponowanej oferty, którzy będą jawnie i aktywnie budować negatywny wizerunek pracodawcy.

Aby uzyskać wskaźnik NPS, należy od procentowego udziału promotorów odjąć procentowy udział krytyków. NPS pozwala na opomiarowanie lojalności klientów poprzez sprawdzenie, jakie rozwiązanie najlepiej spełnia ich potrzeby, powoduje utożsamienie $\mathrm{z}$ firmą oraz emocjonalne przywiązanie do badanego aspektu (Penc, 2008). Wartość NPS obliczamy według wzoru:

\section{NPS $=$ \% promotorów $-\%$ krytyków}

Menedżerowie udzielali odpowiedzi na pytania znajdujące się w tabeli 3. $\mathrm{W}$ badaniu przyjęto założenie zaczerpnięte $\mathrm{z}$ zarządzania procesami, że istnieje analogia między postrzeganiem stosowanych w organizacji rozwiązań przez klienta wewnętrznego i produktu - przez klienta zewnętrznego. Kluczowym aspektem metody jest to, że umożliwia zbadanie satysfakcji oraz 
lojalności klienta, a w tym konkretnym przypadku - pracownika. Dodatkowym atutem metodologii NPS była jej znajomość wśród uczestników, którzy mają bezpośredni kontakt z klientami i agentami. NPS jest częstą metodą oceny ich pracy oraz produktów firmy, w związku z tym została uznana za wiarygodną i miarodajną, biorąc pod uwagę mocno jakościowy charakter prowadzonych praktyk oraz celów.

Tabela 3.

Całościowa ocena NPS praktyk menedżerów sprzedaży

\begin{tabular}{|c|l|}
\hline Pytanie & Wynik NPS \\
\hline Na ile poleciłbyś uczestnictwo w praktykach? & 87 punktów \\
\hline Na ile poleciłbyś jakość materiałów? & 67 punktów \\
\hline Na ile poleciłbyś otwartość na dialog? & 73 punktów \\
\hline
\end{tabular}

Źródło: opracowanie własne.

W formularzu wymagano równocześnie oceny jakościowej w ramach pytań otwartych. Aby dokonać oceny wpływu, każdy z modułów można było ocenić indywidualnie. Wszyscy uczestnicy dobrowolnie wzięli udział w badaniu ankietowym. Ankietowanych poproszono o ocenę wszystkich modułów poprzez wybranie dwóch - najlepszego oraz najgorszego. Żadna z grup nie miała dostępu do wyników ostatecznej listy rankingowej czy punktów ani też do odpowiedzi do pytań otwartych pozostałych uczestników oraz grup. Ankietę wypełniano w formie papierowej.

Analizie poddano wyniki punktowe grup, wyniki NPS oraz odpowiedzi otwarte stu menedżerów sprzedaży (10 z grupy testowej, $90 \mathrm{z}$ grup docelowych). Podział menedżerów na grupy: testową oraz docelowe wynikał $\mathrm{z}$ eksperymentalnej formy wdrożenia rozwiązania, w związku z tym badanie pierwszej miało na celu sprawdzenie prawidłowości działania wszystkich modułów i wychwycenia ewentualnych błędów, luk organizacyjnych czy merytorycznych, które wymagałyby usprawnienia. W tabeli 4 umieszczono zestawienie wyników NPS, które uzyskano w poszczególnych grupach, a także wskazanie najlepszego i najgorszego modułu oraz poziomu efektywności samych uczestników w postaci licznych zdobytych finalnie punktów. 
Tabela 4.

Wyniki ankiety oraz zdobytych punktów w poszczególnych grupach

\begin{tabular}{|c|c|c|c|c|}
\hline $\begin{array}{c}\text { Numer } \\
\text { grupy }\end{array}$ & Wynik NPS & $\begin{array}{c}\text { Moduł wskazany } \\
\text { jako najlepszy }\end{array}$ & $\begin{array}{c}\text { Moduł wskazany } \\
\text { jako najgorszy }\end{array}$ & $\begin{array}{c}\text { Punkty zdobyte przez } \\
\text { pracowników } \\
\text { (maks. 100 punktów) }\end{array}$ \\
\hline 10 & 71 & Moduł 6 & Moduł 2 & 83,037 \\
\hline 9 & 91 & Moduł 6 & Moduł 2 & 82,202 \\
\hline 8 & 100 & Inne & Moduł 1, 2 & 78,325 \\
\hline 7 & 100 & Moduł 6 & Moduł 2, 7 & 82,105 \\
\hline 6 & 100 & Moduł 6 & Moduł 2 & 77,689 \\
\hline 5 & 70 & Moduł 6 & Moduł 2 & 80,123 \\
\hline 4 & 73 & Moduł 6 & Moduł 2, 4 & 81,225 \\
\hline 3 & 100 & Moduł 6 & Moduł 2 & 80,346 \\
\hline 2 & 98 & Inne & Moduł 2 & 86,405 \\
\hline 1 & 92 & Moduł 6 & Moduł 1, 2 & 80,556 \\
\hline
\end{tabular}

Źródło: opracowanie własne.

Na dziesięć grup aż osiem wskazało jako najlepszy moduł numer 6, w którym znajdowało się najwięcej mechanizmów grywalizacyjnych. Warto zaznaczyć, że jednocześnie był to moduł najbardziej wymagający merytorycznie i o największej presji wynikającej z ograniczeń czasowych. W ramach najgorszych modułów wskazano tylko te, które nie zawierały elementów grywalizacji. Dodatkowo warto zwrócić uwagę, że zastosowanie mechanizmów grywalizacyjnych doprowadziło do zwiększenia efektywności wszystkich zespołów, niezależnie od ich cech różnicujących i ani razu nie spadło poniżej 75 punktów na 100 możliwych do zdobycia. Dodatkowo w ośmiu na dziesięć przypadków uczestnicy zdobyli ponad 80 punktów.

\section{Podsumowanie}

Według przestudiowanej literatury, zwiększenie identyfikacji z marką firmy, zbudowanie pozytywnego wizerunku firmy, wymiana doświadczeń oraz integracja pracowników, dzielenie się wiedzą czy wzrost poziomu zaangażowania można osiągnąć poprzez wdrażanie mechanizmów grywalizacyjnych. Dodatkowo im większy poziom zgrywalizowania, tym lepiej. 
Do niewątpliwych zalet grywalizacji można zaliczyć entuzjazm uczestników, łatwiejsze przyswajanie trudnych informacji oraz wzrost motywacji do uzyskiwania większej ich ilości, wzrost liczby zapamiętywanych informacji, zabawa oraz przyjemność z podejmowanych działań, pozytywne doświadczanie trudnych lub nieatrakcyjnych aspektów pracy, łatwiejsze nawiązywanie relacji, budowanie pozytywnego wizerunku pracodawcy oraz realizowanych działań. Zwiększa się również wytrzymałość na obciążenie zadaniami oraz presję czasową. Dodatkowo przy wystarczającej ilości zastosowanych mechanizmów w postaci pozytywnych impulsów pracownicy dobrowolnie i chętnie rezygnują z potrzeby rywalizacji, a swoją pracę przekierowują na współpracę i integrację.

Do utrudnień związanych z grywalizacją możemy zaliczyć wzrastającą czasochłonność w projektowaniu rozwiązania, bo im więcej mechanizmów, tym trudniej je skoordynować. Jeżeli grywalizacja jest offline, organizacja rozwiązań grywalizujących jest trudniejsza do koordynowania w czasie lub wymaga zaangażowania kilku osób koordynujących. Jeżeli jest to rozwiązanie online, wiąże się ono z wysokimi kosztami. Innym utrudnieniem może być nadal brak popularności grywalizacji, przez co trudno początkowo do niej przekonać beneficjentów lub kadrę menedżerską, dopóki sami nie wezmą udziału w grywalizacji. Jednakże mechanizmy grywalizacyjne posiadają ogromny potencjał, nie tylko w zakresie wdrażania ich w organizacjach i przełożenia na ewentualne wyniki, ale także pod względem badawczym.

\section{Literatura}

Czerwiński, A., Czerska, M., Nogalski, B., Rutka, R., Apanowicz, J. (2002). Zarządzanie organizacjami. Toruń: Towarzystwo Naukowe Organizacji i Kierownictwa Stowarzyszenie Wyższej Użyteczności DOM ORGANIZATORA. ISBN 8372850526.

Dembińska-Cyran, I. i Hołub-Iwan, J., Perenc, J. (2004), Zarządzanie relacjami $z$ klientem, Warszawa: Difin. ISBN 8372514305.

Marczewski, A. (2015). Even Ninja Monkeys Like to Play. Wrocław: CreateSpace Independent Publishing Platform. ISBN 9781514745663. ISBN 1514745666.

Paharia, R. (2014). Lojalność 3.0. Warszawa: MT Biznes. ISBN 9788377466285.

Penc, J. (2008), Encyklopedia zarządzania - podstawowe kategorie i terminy. Łódź: Wyższa Szkoła Studiów Międzynarodowych. ISBN 9788360902011. 
Reichheld, F. (2003). One Number You Need to Grow, W: "Harvard Business Review" (December) 2003, s. 8-10.

Tkaczyk, P. (2012). Grywalizacja. Jak zastosować mechanizmy gier w działaniach marketingowych. Gliwice: Onepress. ISBN: 9788324636242. 